\title{
Pola Komunikasi Guru dan Orang Tua dalam Pembinaan Akhlak Peserta Didik
}

\author{
${ }^{1}$ Puji Lestari, ${ }^{2}$ Alauddin \\ 1,2Program Studi Pendidikan Agama Islam, FTIK, IAIN Palopo \\ E-mail: lestari.iainpalopo@gmail.com
}

\begin{abstract}
This study uses a type of qualitative research (qualitative research), which aims.1), to determine the pattern of communication between parents and teachers in the moral development of students in SMA Negeri 2 Sukamaju District. Luwu Utara; 2) To find out the form of moral coaching of parents towards learning that is studying at SMA Negeri 2 Sukamaju district. Luwu Utara;3) to find out the form of moral coaching of students in schools conducted by the teacher; 4) to find out what is the teacher and teacher in the moral development of students. The results showed that 1) the pattern of communication and cooperation between parents and teachers in the moral coaching of students was good enough because there were parents and teachers in fostering the morality of students in SMA 2 Sukamaju; 2) There are several forms of parental moral coaching to students in SMA 2 Sukamaju; 3) Forms of Moral Coaching for Students in SMA 2 Sukamaju can be grouped into two forms of moral coaching, namely morality to humans, and the environment; 4) Constraints in the moral development of students are the family environment, association, and electronic media.
\end{abstract}

Keywords: Communication Pattern, Teacher, Parents, Moral Development

\begin{abstract}
Abstrak
Penelitian ini menggunakan jenis penelitian kualitatif (qualitive research), yang bertujuan.1), untuk mengetahui pola komunikasi antara orang tua dan guru dalam pembinaan akhlak peserta didik di SMA Negeri 2 Sukamaju Kab. Luwu Utara. 2) untuk mengetahui bentuk pembinaan akhlak orang tua terhadap anaknya yang belajar di SMA Negeri 2 Sukamaju kab. Luwu utara.3) untuk mengetahui bentuk pembinaan akhlak peserta didik di sekolah yang dilakukan oleh guru 4) untuk mengetahui faktor apa yang menjadi kendala dan usaha orang tua dan guru dalam pembinaan akhlak peserta didik. Hasil penelitian menunjukan bahwa 1) Pola komunikasi dan Kerja sama antara orang tua dan guru dalam pembinaan akhlak peserta didik sudah cukup baik sebab adanya kerja sama antara orang tua dan guru dalam membina akhlak peserta didik di SMA Negeri 2 Sukamaju. 2) ada beberapa Bentuk Pembinaan Akhlak Orang Tua Terhadap Peserta Didik di SMA Negeri 2 Sukamaju. 3) Bentuk Pembinaan Akhlak terhadap Peserta Didik di SMA Negeri 2 Sukamaju bisa dikelompokan menjadi dua bentuk pembinaan akhlak,yaitu akhlak kepada manusia, dan lingkungan.4)Kendala di dalam pembinaan akhlak peserta didik yaitu lingkungan keluarga, pergaulan, dan media elektronik.
\end{abstract}

Kata Kunci: Pola Komunikasi, Guru, Orang Tua, Pembinaan Akhlak 


\section{Pendahuluan}

Pendidikan akhlak dimaksudkan untuk mengarahkan watak, karakter, dan perilaku kepada perilaku yang telah dicontohkan oleh Rasulullah saw, tentang bagaimana cara berucap, berperilaku serta memperlakukan orang lain secara baik sesuai dengan tatanan akhlak islamiyah. Allah swt. berfirman dalam Qs. al-Ahzab /33:21:

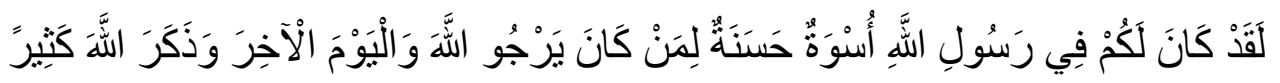

Terjemahnya:

"Sungguh telah ada pada (diri) Rasulullah itu suri tauladan yang baik bagimu (yaitu) bagi orang yang mengharap (rahmat) Allah dan (kedatangan) hari kiamat dan yang banyak mengingat Allah." ${ }^{1}$

Kaitannya dengan kondisi peserta didik di SMA Negeri 2 Sukamajumenurut wakil kesiswaan Bapak Sugianto seperti minum-minuman keras,pelecehan seksual, narkoba, merusak milik orang, balapandijalan raya, perkelahian antar kelompok, mengganggu teman, melawan guru, dan perilaku menyimpang lainnya. sudah menjadi masalah sosial yang sampai saat ini belum dapat diatasi secara tuntas. Akibat yang ditimbulkan cukup serius dan tidak dapat dianggap sebagai suatu persoalan sederhana. Karena sering menjurus kepada tindak kriminal. ${ }^{2}$

Salah satu faktor utama Peneliti mengambil lokasi penelitian tersebut di SMA Negeri 2 Sukamaju, hal itu disebabkan pola pembinaan akhlak yang masih minim dan renggangnya kehidupan peserta didik dari nilai-nilai agama. Perhatian orang tua untuk menanamkan nilai-nilai agama sejak dini pada anak-anak pun sudah mulai menipis.Agama seolah-olah hanya persoalan

${ }^{1}$ Departemen agama RI, al-Qur'anul Karim dan Terjemahannya (Jakarta:Yayasan Penyelenggara Penterjemah al-Qur'an,2008),h.670

2 Sugianto, (WK. Kesiswaan SMA Negeri 2 Sukamaju), wawancara, tanggal 18 September 2016 
ritual dan hubungan pribadi sebagai hamba dengan Tuhannya yang sepenuhnya menjadi urusan Guru di sekolah. Sehingga hal terebut sangat berpengaruh pada akhlak peserta didik untuk melakukan hal-hal yang mengarah pada tindakan yang melanggar tatanan sosial kemasyarakatan. Oleh karena itu, dibutuhkan kerja sama antara orang tua dan guru dalam membentuk dan mengarahkan peserta didik yang mana pada akhirnya melahirkan rasa saling asih, asah dan asuh, dan bahkan menimbulkan perasaan saling memiliki dan bekerja sama antara satu dengan yang lainnya.

\section{Kerangka Teoretis}

Akhlak, kata "akhlaq" berasal dari bahasa Arab, yaitu jama' dari “khuluqun" yang secara linguistik diartikan sebagai budi pekerti, perangai, tingkah laku atau tabiat, tata karma, sopan santun, adab, dan tindakan. ${ }^{3}$ Tabiat atau watak dilahirkan karena hasil perbuatan yang diulang - ulang sehingga menjadi biasa. Perkataan akhlak sering disebut kesusilaan, sopan santun dalam bahasa Indonesia; moral, ethnic dalam bahasa Inggris, dan ethos, ethios dalam bahasa Yunani. Kata tersebut mengandung segi-segi persesuaian dengan perkataan khalqun yang berarti kejadian, yang juga erat hubungannya dengan khaliq yang berarti pencipta; demikian pula dengan makhluqun yang berarti yang diciptakan.

Adapun definisi akhlak menurut istilah ialah kehendak jiwa manusia yang menimbulkan perbuatan dengan mudah karena kebiasaan, tanpa memerlukan pertimbangan pikiran terlebih dahulu.

Berikut ada beberapa pendapat tentang pengertian akhlak itu sendiri

a. Menurut Zuhairini akhlak dalam agama Islam ialah "Suatu ilmu yang dipelajari di dalamnya tingkah laku manusia, atau sikap hidup manusia (the humanconduct) dalam pergaulan hidup". ${ }^{4}$

\footnotetext{
${ }^{3}$ Beni Ahmad Saebani \& Abdul Hamid, Ilmu Akhlak, (Bandung : CV. Pustaka Setia,
} 2010), h. 13

${ }^{4}$ Zuhairini, dkk, Filsafat Pendidikan Islam, (Jakarta : Bumi Aksara, 2008), h. 51 
b. Menurut Imam Al-Ghazali mengemukakan definisi akhlak yaitu sifat yang tertanam dalam jiwa yang daripadanya timbul perbuatan-perbuatan dengan mudah, dengan tidak memerlukan pertimbangan pikiran (lebih dahulu). ${ }^{5}$

Akhlakul karimah atau akhlak terpuji sangat penting dimiliki oleh setiap manusia dimanapun dia berada karena jika seseorang itu berakhlak buruk maka dia akan dicemoohkan orang, dianggap tidak terpelajar dan tidak beradap bahkan lebih pasrah lagi dia akan dianggapkurang ajar. ${ }^{6}$

Kita diperintahkan untuk berbuat baik kepada lingkungan dan jangan merusak apa yang telah diberikan oleh Allah karena itu semua adalah anugerah yang diberikan untuk memanfaatkandengan baik dan digunakan dengan baik.

Misi tersebut tidak lepas dari tujuan tingkatannya manusia sebagai khalifah dimuka bumi yang bertugas memakmurkan, mengelola, dan melestarikan alam.

Memelihara dan membina perkembangan remaja biasanya disebut mendidik dan itu pulalah fungsi dan peranan pendidikan agama Islam. Untuk memelihara dan membina moral remaja dengan sebaik-baiknya maka perlu disadari apa tujuan dari pertumbuhan dan perkembangan. Oleh karena itu menjadikan seseorang dengan kepribadian yang berintegrasi dalam aspekaspek psikis,fisik,moral dan spiritual. Syarat-syarat pokok dalam pembinaan dan perkembangan remaja adalah:

1. Adanya pembinaan yang bertanggung jawab dalam hal ini orang tua dan guru disekolah. Dalam pembinaan seseorang harus memahami sifat-sifat peserta didik dan juga tau cara-cara mendidik.

${ }^{5}$ Zainuddin dan Muhammad Jamhari, Al-islam 2muamalah dan Akhlak, (semarang:cv pustaka setia, 2000),h.74

${ }^{6}$ M.Attar.Semi, Sopan Santun Berbicara Dan Menyimak, (Bandung: Titian ilmu,1998),h.3 
2. Tersedianya alat-alat, artinya bahwa dalam membina remaja diperlukan perlengkapan memadai dan memungkinkan tugas-tugas pembinaan terlaksana dengan sebaik-baiknya.

3. Pembinaan terhadap peserta didik diperlukan adanya keteraturan dalam arti membina harus diberikan secara terus-menerus dan berkeseimbangan.

4. Diperlukan adanya perlindungan dari rasa takut dalam melaksanakan aktifitasnya.

5. Adanya kesadarandan ketekunan seorang pendidik peserta anak didiknya, karena merupakan suatu proses maka membutuhkan waktu yang panjang. ${ }^{7}$

Telah menjadi kenyataan bahwa dari hari depan diraih melalui pendidik yang baik pula. Akan tetapi pendidikan yang peneliti maksudkan adalah bukan pendidikan formal semata, melainkan pendidikan non formal yang didapat langsung dari orang tua dan masyarakat dimana dia hidup. Jadi, dalam hal ini yang menentukan corak dan warna adalah pendidikan dari orang tua dan peniru dari masyarakat.

Menurut obyek atau sasarannya terdapat akhlak kepada Allah swt, akhlak kepada manusia dan akhlak kepada lingkungan. Berikut pembahasannya :

a. Akhlak kepada Allah

1) Beribadah kepada Allah, yaitu melaksanakan perintah Allah untuk menyembah-Nya sesuai dengan printah-Nya.

2) Berzikir kepada Allah, yaitu mengingat Allah dalam berbagai situasi dan kondisi, baik diucapkan dalam mulut maupun dengan hati. Berzikir kepada Allah dapat melahirkan ketenangan dan ketentraman hati. 
3) Berdoa kepada Allah, memohon kepada-Nya, doa merupakan inti ibadah karena ia merupakan pengakuan akan keterbatasan dan ketidak mampuan manusia, sekaligus pengakuan akan kemahakuasaan Allah.

4) Tawakkal kepada Allah, yaitu berserah diri sepenuhnya kepada Allah swt, dan menunggu hasil pekerjaan atau menanti akibat dari suatu keadaan, sebagaimana firman Allah Q.S Hud/11:123:

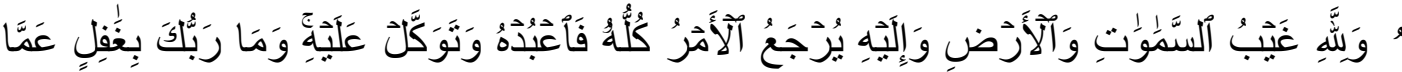

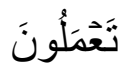

Terjemahnya:

"Dan kepunyaan Allah-lah meliputi rahasia langit dan bumi dan kepadaNya segala urusa dikemblikan.maka sembahlah Dia, dan bertawakkallah kepada-Nya. Dan sekali-kali Tuhan-Mu tidak akan lengah terhadap apa yang kamu kerjakan". ${ }^{8}$

5) Tawaduk kepada Allah adalah rendah hati dihadapan-Nya, mengakui bahwa diri ini tidak apa-apanya dihadapan-Nya yang harus dipertanggungjawabkan.

b. Akhlak kepada manusia

1) Akhlak kepada diri sendiri

a) Sabar, adalah perilaku seseorang kepada dirinya sendiri sebagai hasil dari pengendalian nafsu dan penerimaan terhadap apa yang menimpanya.

b) Syukur, adalah sikap berterima kasih atas pemberian nikmat Allah yang tidak terhitung banyaknya, yang diungkapkan dalam bentuk ucapan dan perbuatan, yaitu dengan mengucapkan Alhamdulillah dan memanfaatkan nikmat-Nya dengan baik.

${ }^{8}$ Departemen Agama RI,Al-Qur'ánul karim dan terjemahnya (Diponeggoro Bandung penyelenggara penterjemah Al-Qurán, 2008),h. 230 
c) Tawaduk, yaitu rendah hati, menghargai orang lain baik tua, muda, kaya, miskin karena semuanya sama dihadapan Allah, yang membedakan hanyalah ketaqwaan seseorang

c. Akhlak kepada ibu bapak

yaitu dengan cara berbuat baik kepada keduannya dengan ucapan dan perbuatan. Allah telah memerintahkan kepada manusia agar berbuat baik kepada orang tuannya. Sebagaimana dalam firman-Nya Q.S Luqman/31:14

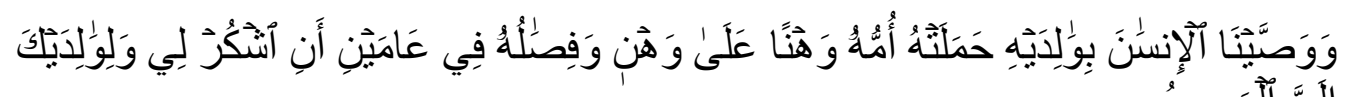

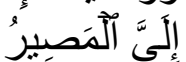

Terjemahnya:

"Dan kami perintahkan kepada manusia (berbuat baik)kepada dua orang ibu-bapaknya telah mengandungnya dalam keadaan lemah yang bertambah-tambah, dan menyapihnya dalam dua tahun, bersyukurlah kepadaku dan kepada dua orang ibu bapakmu, hanya kepada-Kulah kembalimu. ${ }^{9}$

d. Akhlak kepada keluarga

Akhlak kepada keluarga adalah mengembangkan kasihsayang diantaraanggota keluarga yang diungkapkan dalam bentuk prihatin baik melaluiperkataan, maupun perilaku sehingga dapat dirasakan oleh seluruh keluarga"10

e. Akhlak kepada lingkungan hidup

Misi agama Islam adalah mengembangkan rahmat yang bukan hanya kepada manusia tetapi juga kepada alam dan lingkungan hidup, sebagaimana firman Allah Q.S al-Anbiyya'/21:107:

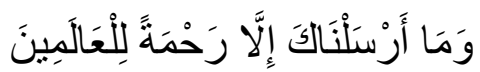

Terjemahnya: "Dan tidaklah kami mengutus kamu, melainkan untuk (menjadi) rahmat bagi semesta alam"11

${ }^{9}$ Departemen Agama RI,Al-Qur'ánul karim dan terjemahnya (Diponeggoro Bandung penyelenggara penterjemah Al-Qurán, 2008),h. 331

${ }^{10}$ Azumary Azra, Buku Teks Agama Islam, (Cet.III: September 2002),h.205-206.

${ }^{11}$ Departemen agama RI, op.cit.,2002,h.508 
Urgensi Akhlak dalam Berinteraksi di Lingkungan Keluarga, Sekolah dan Masyarakat.

Akhlakul karimah atau akhlak terpuji sangat penting dimiliki oleh setiap manusia dimanapun dia berada karena jika seseorang itu berakhlak buruk maka dia akan dicemoohkan orang, dianggap tidak terpelajar dan tidak beradap bahkan lebih pasrah lagi dia akan dianggapkurang ajar. ${ }^{12}$

Kita diperintahkan untuk berbuat baik kepada lingkungan dan jangan merusak apa yang telah diberikan oleh Allah karena itu semua adalah anugerah yang diberikan untuk memanfaatkandengan baik dan digunakan dengan baik.

Misi tersebut tidak lepas dari tujuan tingkatannya manusia sebagai khalifah dimuka bumi yang bertugas memakmurkan, mengelola, dan melestarikan alam.

Memelihara dan membina perkembangan remaja biasanya disebut mendidik dan itu pulalah fungsi dan peranan pendidikan agama Islam. Untuk memelihara dan membina moral remaja dengan sebaik-baiknya maka perlu disadari apa tujuan dari pertumbuhan dan perkembangan. Oleh karena itu menjadikan seseorang dengan kepribadian yang berintegrasi dalam aspekaspek psikis,fisik,moral dan spiritual. Syarat-syarat pokok dalam pembinaan dan perkembangan remaja adalah:

1. Adanya pembinaan yang bertanggung jawab dalam hal ini orang tua dan guru disekolah. Dalam pembinaan seseorang harus memahami sifat-sifat peserta didik dan juga tau cara-cara mendidik.

2. Tersedianya alat-alat, artinya bahwa dalam membina remaja diperlukan perlengkapan memadai dan memungkinkan tugas-tugas pembinaan terlaksana dengan sebaik-baiknya.

${ }^{12}$ M.Attar.Semi, Sopan Santun Berbicara Dan Menyimak, (Bandung: Titian ilmu,1998),h.3 
3. Pembinaan terhadap peserta didik diperlukan adanya keteraturan dalam arti membina harus diberikan secara terus-menerus dan berkeseimbangan.

4. Diperlukan adanya perlindungan dari rasa takut dalam melaksanakan aktifitasnya.

5. Adanya kesadarandan ketekunan seorang pendidik peserta anak didiknya, karena merupakan suatu proses maka membutuhkan waktu yang panjang. ${ }^{13}$

Telah menjadi kenyataan bahwa dari hari depan diraih melalui pendidik yang baik pula. Akan tetapi pendidikan yang peneliti maksudkan adalah bukan pendidikan formal semata, melainkan pendidikan non formal yang didapat langsung dari orang tua dan masyarakat dimana dia hidup. Jadi, dalam hal ini yang menentukan corak dan warna adalah pendidikan dari orang tua dan peniru dari masyarakat

\section{Pola Pembinaan Akhlak Peserta Didik}

Sebagian besar pemikiran akhlak Ibnu Maskawaih lebih bercorak keagamaan, terutama paham sufi. Pembinaan akhlak menurutnya dititik beratkan kepada pembersihan pribadi dari sifat-sifat yang berlawanan dengan tuntutan agama, seperti : takabur, pemarah dan penipu. Keluhuran akhlak sebagai media untuk menduduki tingkat kepribadian remaja yang berbobot Islam.

Dengan pembinaan akhlak ingin dicapai terwujudnya manusia yang ideal; anak yang bertakwa kepada Allah swt dan cerdas. Dengan teori akhlaknya, Ibnu Maskawaih bertujuan untuk menyempurnakan nilai-nilai kemanusiaan sesuai dengan ajaran Islam yang taat beribadah dan sanggup hidup bermasyarakat yang baik.

Menurut Drs. Agus Suyanto, di dunia pendidikan pembinaan akhlak tersebut dititik beratkan kepada pembentukan mental anak atau remaja agar

\footnotetext{
${ }^{13}$ Ibnu Maskawai, Menuju Kesempurnaan Akhlak, (Cet, V; Bandung: Mizan 1994),h.57
} 
tidak mengalami penyimpangan. Dengan demikian akan mencegah terjadinya "Juvenile Delinquency" yang berarti kenakalan anak.Sebab pembinaan akhlak berarti bahwa anak remaja dituntut agar belajar memiliki rasa tanggung jawab.

Manfaat lain dari pembinaan akhlak menurut Ibnu Maskawai yakni : terhindarnya anak-anak remaja dari tabiat-tabiat tercela dan sebagai langkah penanggulangan terhadap timbulnya kenakalan remaja. Dengan demikian menurut Ibnu Maskawai dapat memberi sumbangan positif bagi ketentraman dan keamanan masyarakat dari kejahatan pada umumnya ; terutama dari gangguan kenakalan remaja. Sebab pada hakikatnya penjahat yang sudah dewasa merupakan perkembangan lebih lanjut dari kebiasaan melakukan kejahatan di waktu kecil; pada masa-masa perkembangan mental, yakni: masa remaja. ${ }^{14}$

\section{Metode dan Hasil Penelitian}

Penelitian ini merupakan penelitian kualitatif yang dilakukan di SMA Negeri 2 Sukamaju yang beralamat di Rawamangun lorong 1 C. Adapun yang menjadi batasan lokasi penelitian adalah peserta didik di SMA Negeri 2 Sukamaju dan waktu yang digunakan selama penelitian adalah 1 (satu) bulan Di antara model komunikasi antara guru dan orang tua di SMA Negeri 2 Sukamaju adalah sebagai berikut:

\section{Komunikasi langsung}

Komunikasi langsung adalah komunikasi yang dilakukan oleh pihak sekolah yaitu para wali kelas atau guru Bimbingan konseling mengunjungi langsung orang tua peserta didik dan menanyakan atau mendiskusikan langsung dengan orang tua atau wali peserta didik tentang perlunya pembinaan akhlak baik yakni akhlak yang berhubungan langsung dengan Allah swt. maupun sesama manusia seperti orang tua dan masyarakat. Akhlak

\footnotetext{
${ }^{14}$ Sudarsono, Etika IslamTentang Kenakalan Remaja; (Jakarta:Rineka Cipta, 2005). Cet.IV, hal. 147-149
} 
kepada Allah itu sendiri seperti melaksanakan sholat dengan istiqomah, berdzikir, berdoa kepada Allah swt, tawakal dan tawaduk kepada Allah swt. sedangkan akhlak kepada sesama manusia seperti akhlak kepada diri sendiri, akhlak kepada keluarga, dan akhlak kepada lingkungan. ${ }^{15}$

2. Komunikasi tidak langsung

Komunikasi tidak langsung adalah komunikasi yang terjadi dimana pesan-pesan yang disampaikan berlangsung dengan menggunakan perantara. Dalam hal ini komunikasi tidak langsung dilakukan oleh pihak sekolah dalam hal ini kepala sekolah SMA Negeri 2 Sukamaju, yakni mengundang orang tua peserta didik pada saat penerimaan rapor. Dalam pertemuan tersebut dibicarakan mengenai pola pembinaan akhlak terhadap peserta didik di SMA Negeri 2 Sukamaju .

Selain itu juga, komunikasi dilakukan setiap awal tahun ajaran baru, di mana pihak sekolah mengundang orang tua. Dalam hal ini membicarakan tentang komite sekolah dan dibicarakan tentang pentingnya pembinaan akhlak yang dilakukan secara terpadu. Dalam hal ini bukan hanya pihak sekolah yang bertanggung jawab tetapi orang tua yang lebih utama dalam pembinaan akhlak peserta didik di SMA Negeri 2 Sukamaju. ${ }^{16}$

Dengan demikian, untuk membentuk kepribadian peserta didik yang mulia dibutuhkanlah kerja sama antara orang tua dan guru. Sehingga proses kerja sama antara orang tua dan guru inilah menjadi salah satu faktor terpenting dalam pembentukan akhlak peserta didik, khususnya di SMA Negeri 2 Sukamaju. Dari hasil penelitian yang peneliti temukan bahwa ada pola komunikasi atau bentuk kerja sama antara orang tua dan guru dalam proses pembinaan akhlak peserta didik di SMA Negeri 2 Sukamaju, seperti pada saat pembagian rapor pihak sekolah tidak memberikan langsung rapor tersebut kepada peserta didik, namun pihak sekolah membuat persuratan

${ }^{15}$ Sugianto, (WK.Urs. kesiswaan SMA Negeri 2 Sukamaju) wawancara tanggal 17 september 2016

${ }^{16}$ Ninik asanah, (Wk. Urs. HumasSMA Negeri 2 Sukamaju) wawancara 18September 2016 
guna untuk mengundang orang tua atau wali peserta didik untuk pembagian rapor dan sekaligus menyampaikan beberapa sifat keseharian peserta didik selama di ruang lingkup sekolah. Kegiatan ini rutin dilakukan setiap akhir semester untuk menjalin hubungan kerja samaantara pihak sekolah dan orang tua dalam pembinaan akhlak peserta didik di SMA Negeri 2 Sukamaju ketika terjadi masalah atau pelanggaran yang dilakukan oleh peserta didik. ${ }^{17}$

Lingkungan keluarga merupakan institusi dalam proses perkembangan manusia seutuhnya. Oleh sebab itu, setiap anggota keluarga dalam rumah tangga muslim berkewajiban untuk membangun rumah tangganya menjadi rumah tangga atau keluarga yang sejahtera, bahagia lahir batin, dimana suasana dan ketentraman hidup tercipta di dalamnya. Pembangunan rumah tangga atau keluarga yang sejahtera merupakan kewajiban kedua setelah pembinaan pribadi. Pembangunan rumah merupakan langkah pertama dalam melaksanakan hubungan kemasyarakatan (hablunmin al-nas).

Menurut ibu Emi sebagai salah satu orang tua peserta didik, terdapat beberapa pembinaan akhlak yang dilakukan dalam lingkungan keluarga untuk diterapkan di sekolah, antara lain: ${ }^{18}$

1) Pembinaan budi pekerti dan sopan santun kepada sesama manusia

2) Pembinaan bersikap jujur pada saat ujian. Selain itu juga, diajarkan untuk disiplin waktu masuk sekolah, dan disiplin cara berpakaian yang rapi.

3) Pembinaan akhlak yang saling menghormati antar siswa di sekolah. ${ }^{19}$

${ }^{17}$ Sugianto, (WK.Urs. kesiswaan SMA Negeri 2 Sukamaju) wawancara tanggal 17 september 2016

${ }^{18} \mathrm{Emi}$, (orang tua peserta didik SMA Negeri 2 Sukamaju) wawancara 17 September 2016

${ }^{19}$ Jannah , (orang tua peserta didik SMA Negeri 2 Sukamaju) wawancara 17 september 2016 
Sementara menurut Ibu siti fatmawati "sebagai peserta didik yang boleh dikatakan sebagai anak edukatif harus mengikuti arahan-arahan guru di sekolah, sejak itu arahan-arahan yang sesuai dengan norma-norma agama atau aturan yang diberikan di sekolah."20

Itulah beberapa pola pembinaan yang dilakukan oleh orang tua di SMA Negeri 2 Sukamaju, dalam hal ini pembinaan akhlak.

Menurut Bapak Sugianto sebagai Wk.Urs. kesiswaan "bentuk pembinaan peserta didik secara umum ada 3 yaitu:

1. Pembinaan akhak yang berkaitan dengan Allah, Seperti ibadah sholat. Peserta didik dibimbing langsung oleh guru Agama mengenai praktek ibadah sholat dan itu dilakukan langsung di masjid.

Namun, menurut Bapak Muh. Fauzi "bukan hanya peserta didik dibimbing atau ditekankan untuk memelihara sholat 5 waktu. Akan tetapi, peserta didik juga dibimbing mengenai praktek-praktek sholat sunnah. Seperti, sholat dhuha, sholat tahajjud, dan lain sebagainya." ${ }^{21}$

2. Pembinaan akhlak yang berkaitan dengan sesama manusia, seperti sopan santun, ramah, sabar, saling menghargai, tolong menolong dan lain sebagainya.

Akhlak kepada manusia identik dengan sosialisasi dalam mu'amalah , dimana di dalamnya mencakup segala aktivitas manusia dengan fungsi tugas dan jabatan yang diembannya, sehingga manusia disebut sebagai makhluk social.

"Dalam konteks pembinaan...selain kedua orang tua, guru-guru pun harus dihormati, karena merekalah yang mendidik dan menunjukan kepada kebaikan dan kebahagiaan. Gurulah yang mengajar cara menulis, membaca, mengajarkan aneka ilmu pengetahuan. Dengan demikian, menghormati guru seharusnya sama dengan menghormati kedua orang tua"22

\footnotetext{
${ }^{20}$ Siti fatmawati, , (orang tua peserta didik SMA Negeri 2 Sukamaju) wawancara 18 september 2016

${ }^{21}$ Muh. Fauzi, (wali kelas XI IPA 2 SMA Negeri 2 Sukamaju) wawancara 18 September 2016

${ }^{22}$ Siti fatimah (Guru Pendidikan Agama Islam) wawancara , SMA Negeri 2 Sukamaju 18 September 2016
} 
Sedangkan menurut ibu fatmawati "Adapun pembinaan akhlak yang berkaitan dengan sesama manusia yaitu peserta didik diarahkan untuk senantiasa menghormati semua komponen warga sekolah, guru, dan pegawai, saling tolong menolong terhadap teman-teman peserta didik lainnya"23

Dari uraian di atas, maka dapat dipahami bahwa akhlak terhadap sesama manusia secara umum serta akhlak terhadap kedua orang tua dan guru harus dijalin dengan sebaik-baiknya, sehingga tercipta perilaku keberagaman sesuai dengan petunjuk syariat.

"Beberapa strategi yang bisa dilakukan dalam rangka membina akhlak peserta didik di SMA Negeri 2 Sukamaju kab. Luwu Utara yakni 1). Menjauhkan anak dari pergaulan yang tidak baik, 2) membiasakan untuk bersopan santun, 3) menanamkan sifat sederhana, 4) tidak diperkenankan peserta didik untuk menyontek pekerjaan temannya saat ujuan berlangsung, 5) mengizinkan bermain setelah belajar, namun tetap dalam pengawasan guru maupun satpam di lingkungan sekolah." ${ }^{24}$

3. Pembinaan akhlak yang berkaitan dengan disiplin mengikuti tata tertib sekolah.

Yaitu dimana peserta didik diharuskan mengikuti tata tertib yang berlaku di sekolah dan apabila melanggar tata tertib tersebut maka akan dikenakan sanksi. ${ }^{25}$

Dalam halini siswa diajarkan dan diarahkan melakukan kegiatan untuk diri sendiri. Hal ini ditegaskan lagi oleh Ibu Ninik selaku WK.Urs Humas di SMA Negeri 2 Sukamaju mengatakan:

"Salah satu model pembinaan akhlak dengan pendekatan pembiasaan perilaku peserta didik untuk mengikuti tata tertib sekolah adalah dengan cara mengarahkan peserta didik untuk berbuat untuk dirinya sendiri, misalnya meminta izin bila akan memakai barang orang lain dan mengembalikan pada tempatnya, meminta izin apabila ada keperluan di luar lingkungan sekolah, bertanggung jawab terhadap tugas yang

\footnotetext{
${ }^{23}$ Fatmawati (Wali kelas XII IPA 3) wawancara, SMA Negeri 2 Sukamaju tanggal 18 September 2016

${ }^{24}$ Sugianto, (WK.Urs. kesiswaan) wawancara, SMA Negeri 2 Sukamaju tanggal 10 februari 2017

${ }^{25}$ Sugianto, (WK.Urs. kesiswaan SMA Negeri 2 Sukamaju) wawancara tanggal 18 September 2016
} 
dibebankan, berani untuk berkata benar, merasa malu bila berbuat kesalahan dan mengakuinya, dan lain sebagainya." 26

Adapun menurut Bapak kepala sekolah SMA Negeri 2 Sukamaju "peserta didik diarahkan untuk mengikuti tata tertib di sekolah seperti tepat waktu masuk jam pelajaran, disiplin mengikuti proses belajar mengajar, disiplin mengerjakan tugas-tugas yang dibebankan oleh setiap guru di sekolah. Selain itu, peserta didik diarahkan disiplin mengikuti upacara baik upacara yang dilakukan setiap hari senin, maupun upacara yanglainnya seperti, upacara peringatan 17 Agustus 1945 dan hari-hari besar lainnya." 27

Dengan pendekatan pembiasaan yang baik, maka diharapkan peserta didik memiliki kepribadian yang tangguh dan tidak mudah tergoyahkan sehingga tidak tertarik untuk mengikuti budaya-budaya negatif dari luar yang tidak sesuai dengan kultur budaya di Negara Indonesia.

"Beberapa strategi yang bisa dilakukan dalam rangka membina akhlak peserta didik di SMA Negeri 2 Sukamaju kab. Luwu Utara yakni 1). Menjauhkan anak dari pergaulan yang tidak baik, 2) membiasakan untuk bersopan santun, 3) menanamkan sifat sederhana, 4) tidak diperkenankan peserta didik untuk menyontek pekerjaan temannya saat ujuan berlangsung, 5) mengizinkan bermain setelah belajar, namun tetap dalam pengawasan guru maupun satpam di lingkungan sekolah." 28

Dari uraian di atas, peneliti bisa simpulkan bahwa begitu penting adanya pembinaan akhlak kepada peserta didik di lingkungan keluarga maupun di sekolah. Dimana orang tua dan guru harus benar-benar mendidik dan membina peserta didik dengan sebaik-baiknya sehingga tercipta generasi muda yang cerdas dan berakhlakul karimah, ada beberapa faktor yang berpengaruhi signifikan terhadap pembentukan akhlak peserta didik di dalam lingkungan keluarga maupun di sekolah, yaitu:

\footnotetext{
${ }^{26}$ Ninik asanah, (Wk. Urs. Humas SMA Negeri 2 Sukamaju,) “wawancara, 18September 2016

${ }^{27}$ Kepala Sekolah SMA Negeri 2 Sukamaju, Wawancara tanggal 18 September 2016

${ }^{28}$ Sugianto, (WK.Urs. kesiswaan SMA Negeri 2 Sukamaju) wawancara tanggal 18 februari 2016
} 


\section{Lingkungan keluarga}

Menurut Wk.Urs. Humas ibu Ninik hasanah

"Kesalahan orang tua dalam berinteraksi dan berkomunikasi kepada anak. Seperti membentak, berbicara kotor, kurangnya perhatian orang tua terhadap anak, dan lainnya. Maka dari tindakan orang tua yang seperti itulah terjadi ketidakstabilan mental kepribadian anak. Ketidakstabilan inilah yang biasanya akan terbawa di sekolah dan akan mengakibatkan kesulitan-kesulitan belajar". ${ }^{29}$

Oleh karena itu, orang tua harus menjadi teladan yang harus dijadikan uswah oleh anaknya. Setiap gerak bibir kedua orang tua berucap, dan anggota tubuh berbuat dan bersikap adalah cerminan bagi anaknya.

Dorothy Law Nolte sebagaimana yang dikutip oleh Cahyadi Takariawan melukiskan dalam syairnya, yaitu:

"Bila anak sering dikritik, ia belajar mengumpat. Bila anak sering dikasari, ia belajar berkelahi. Bila anak sering diejek, ia belajar menjadi pemalu. Bila anak sering dipermalukan, ia belajar merasa bersalah. Bila anak sering dimaklumi, ia akan belajar menjadi sabar. Bila anak sering disemangati, ia belajar menghargai. Bila anak mendapatkan haknya, ia belajar betindak adil. Bila anak merasa aman, ia belajar percaya. Bila anak diterima dan diakrabi, ia akan menemukan cinta. ${ }^{30}$

\section{Lingkungan pergaulan}

Menurut Ibu Fatimah salah seorang tenaga pendidik di SMA Negeri 2 Sukamaju tersebut mengatakan:

"Pengaruh lingkungan pergaulan menyebabkan sebagian peserta didik SMA Negeri 2 Sukamaju menjadi pribadi yang ikut-ikutan. Karena pengaruh teman-temannya yang tidak sekolah, kadang mereka ada yang merokok atau bolos sekolah hanya untuk nongkrong dipinggir jalan. Dalam kondisi yang demikian membuat guru dan Pembina sedikit tegas dalam membuat efek jera kepada peserta didik. ${ }^{31}$ Bahkan yang lebih rawan jika mereka sudah bersentuhan atau mengenal dengan minuman keras bisa-bisa mereka menjadi generasi yang tak terkendali. Untuk

${ }^{29}$ Ninik hasanah (WK. Urs. Humas SMA Negeri 2 Sukamaju) wawancara tanggal 18September 2016

${ }^{30}$ Cahyadi Takariawan, Pernik-Pernik Rumah Tangga Islami, (Cet II; Solo :intermedia, 2002 h. 276

${ }^{31}$ Patimah, guru Agama Islam SMA Negeri 2 Sukamaju, wawancara di Rawamangun tanggal 17 september 2016 
itulah orang tua dan guru berusaha sekuat tenaga untuk mengarahkan peserta didik."

Oleh karena itu, masyarakat seharusnya menyediakan lingkungan yang kondusif bagi perkembangan mental peserta didik. Dan dalam hal ini orang tua memberi arahan yang baik kepada peserta didik (anaknya) dan membatasi waktu jalan anak misalnya jam 9 malam harus pulang. Jika anak melanggar aturan dari orang tua maka, salah satu konsekuensi yang diberikan kepada peserta didik yaitu tidak diberikan kendaraan untuk pergi ke sekolah atau disita handpone.

\section{Pengaruh media elektronik}

Peningkatan media telekomunikasi dan elektronik yang begitu pesatnya, membuat dunia yang begitu luas terasa sangat dekat dengan kita. Apa yang terjadi di belahan dunia manapun akan mudah kita pantau dari dalam rumah kita dengan media televise, VCD, parabola, internet dan lain-lain. Dalam kondisi seperti ini, maka informasi-informasi yang positif akan terekam oleh peserta didik, demikian juga sebaliknya nilai-nilai negatif juga akan menjadi tontonan anak setiap hari.

Salah seorang guru mengatakan "Ada beberapa dampak positif dan negatif dari media elektronik yaitu nilai dan informasi yang positif misalnya peserta didik bisa menyaksikan berbagai acara-acara televisi yang bernuansa keagamaan, perkembangan teknologi yang membuat peserta didik terbuka wawasannya, dan budaya bangsa kita yang tersebar di seluruh dunia. Demikian juga sebaliknya nilai-nilai negatif juga bisa diserap anak misalnya dalam hal gaya hidup. Ada yang meniru gaya hidup dengan rambut pirangnya, pergaulan yang tidak jelas antara laki-laki dan perempuan juga kepemilikan terhadap barang yang dapat menaikkan gengsi mereka dihadapan teman-temannya, misalnya HP, dan alat-alat komunikasi lainnya, bahkan terkadang bersifat sedikit memaksa untuk membelinya." ${ }^{32}$

${ }^{32}$ Patimah, guru Agama Islam SMA Negeri 2 Sukamaju, wawancara di Rawamangun tanggal 17 september 2016 
Persoalan perkembangan arus informasi dan tekologi sekarang ini memang tidak bisa dihindari. Tetapi paling tidak media atau pemerintah bisa membuat kebijakan untuk melindungi kepentingan jangka panjang pedidikan dalam rangka menciptakan sumber daya manusia yang handal dan memiliki kapasitas moral yang memadai. Orang tua di rumah juga bisa memantau pemanfaatan tekologi oleh anak-anak mereka dan membatasi penggunaan media elektronik yang berlebihan dan selalu mengingatkan untuk bergaul dengan teman yang baik. Karena jika tidak maka hal-hal yang buruk bisa saja terjadi. Misalnya pornografi, pelecehan seksual,perkelahian dan lain sebagainya.

Sekaitan dengan hal tersebut, maka ada beberapa metode yang harus digunakan dalam pembinaan akhlak peserta didik di sekolah maupun di rumah, yaitu sebagai berikut:

\section{Contoh teladan}

Keteladanan dalam pembinaan merupakan bagian dari sejumlah metode paling ampuh dan efektif dalam mempersiapkan dan membentuk anak secara moral, spiritual, dan social. Sebab keluarga dalam hal ini guru merupakan contoh ideal bagi anak-anaknya. Tingkah laku dan sopan santunnya akaan ditiru, disadari atau tidak, bahkan semua keteladanan itu akan melekat pada diri anak dan kebiasaan, baik dalam bentuk ucapan maupun perbuatan.

Dengan demikian, orang tua dan guru hendaknya mengetahui dan menyadari bahwa pembinaan dengan keteladanan merupakan tiang penyangga dalam upaya meluruskan penyimpangan moral dan perilaku peserta didik. Oleh karena itu orang tua dan guru yang tidak dapat memberikan contoh teladan yang baik kepada peserta didik, jangan diharapkan dapat membimbing anak/peserta didik kepada kebaikan yang diharapkannya. 


\section{Adat kebiasaan}

Membiasakan sesuatu amal dengan tigkah laku seperti melatih peserta didik untuk mengerjakan sholat, mengucapkan salam, basmalah, hamdalah, mengucapkan terimakasih, cara bertamu, menjaga ucapan (lisan), serta tingkah laku lainnya yang akan membentuk kepribadian peserta didik yag jauh lebih baik dari sebelumnya.

3. Metode nasihat

Nasihat sangat berperan dalam menjelaskan kepada anak tentang segala hakikt, menghiasinya dengan moral mulia, dan mengajarinya tentang prinsip-prinsip Islam.

4. Metode pengawasan

Metode pengawasan yang dimaksud adalah mendampingi peserta didik dalam rangka membentuk akidah dan moral. Dan mengawasinya dalam mempersiapkan secara psikis dan social. Dan menanyakan secara terus menerus tentang keadaannya, baik dalam pembinaan jasmani maupun dalam hal belajarnya.

5. Metode ta'lim

Metode ta'lim merupakan metode dasar dalam pembinaan, bahkan dalam aktivitas komunikasi antara seseorang dengan orang lain. Contoh penerapan dalam bidang pembinaan agama yaitu seperti, 1) dalam bidang akidah, 2) dalam bidang ibadah, 3) dalam bidang akhlak.

\section{Penutup}

Pola komunikasi dan Kerja sama antara orang tua dan guru dalam pembinaan akhlak peserta didik sudah cukup baik sebab adanya kerja sama antara orang tua dan guru dalam proses pembinaan akhlak peserta didik di SMA Negeri 2 Sukamaju, terjadi pada saat pembagian rapor, adanya kasus perkelahian, jarang menghadiri proses belajar mengajar (alpa/sakit). 
Bentuk Pembinaan Akhlak Orang Tua Terhadap Peserta Didik di SMA Negeri 2 Sukamaju, yaitu: 1) dititik beratkan kepada pembentukan mental peserta didik agar tidak mengalami penyimpangan. 2) bahwa peserta didik dituntut agar belajar memiliki rasa tanggung jawab, 3) adanya perhatian dan arahan yang baik dari orang tua, 4) merubah sikap buruk peserta didik.

Kendala di dalam pembinaan akhlak peserta didik yaitu 1) lingkungan keluarga, dimana terletak pada kesalahan orang tua dalam berinteraksi dengan anaknya, dan kurangnya perhatian dari orang tua sehingga, anak pun sulit untuk di atur. 2) lingkungan pergaulan yang menyebabkan peserta didik menjadi pribadi yang ikut-ikutan sehingga terjadi penyimpangan. 3) media elektronik seperti Handpone, televisi, leptop, dan lain sebagainya.

Sedangkan upaya yang harus dilakukan dalam rangka membina akhlak peserta didik di SMA Negeri 2 Sukamaju adalah 1) contoh teladan, 2) adat kebiasaan, 3) metode nasihat, 4) metode pengawasan, 5) metode ta'lim.

\section{Daftar Pustaka}

Departemen agama RI, al-Qur'anul Karim dan Terjemahannya. Jakarta:Yayasan Penyelenggara Penterjemah al-Qur'an, 2008.

Maskawai, Ibnu. Menuju Kesempurnaan Akhlak, Cet, V; Bandung: Mizan, 1994. Saebani, Beni Ahmad \& Abdul Hamid. Ilmu Akhlak, Bandung : CV. Pustaka Setia, 2010.

Semi, M.Attar., Sopan Santun Berbicara Dan Menyimak, Bandung: Titian Ilmu,1998.

Sudarsono, Etika IslamTentang Kenakalan Remaja. Jakarta: Rineka Cipta, 2005. Takariawan, Cahyadi. Pernik-Pernik Rumah Tangga Islami. Cet II; Solo : Intermedia, 2002.

Zainuddin dan Muhammad Jamhari, Al-islam 2 Muamalah dan Akhlak. Semarang: CV Pustaka Setia, 2000.

Zuhairin, dkk, Filsafat Pendidikan Islam. Jakarta : Bumi Aksara, 2008. 